\title{
High-Redox Potential Cathode Based on Laccase \\ Covalently Attached to Gold Electrode
}

Marcos Pita* ${ }^{1+}$, Cristina Gutierrez-Sanchez $z^{1+}$, David Olea ${ }^{1}$, Marisela Velez ${ }^{l}$, Cristina García-Diego ${ }^{l}$, Sergey Shleev ${ }^{2}$, Victor M. Fernandez ${ }^{1}$, Antonio L. De Lacey* ${ }^{1}$.

${ }^{*, 1}$ Instituto de Catalisis y Petroleoquimica, CSIC. C/ Marie Curie 2, 28049 Madrid, Spain. Telephone: +34915854802. Fax: +34915854760. E-mail addresses marcospita@icp.csic.es, alopez@icp.csic.es.

${ }^{2}$ Biomedical Laboratory Science and Technology, Faculty of Health and Society, Malmö University, SE-205 06 Malmö, Sweden

* These authors contributed equally to this work.

Article published in Journal of Physical Chemistry C (ACS), June $17^{\text {th }} 2011$.

DOI: $10.1021 / j p 203643 h$

Please cite as follows: J. Phys. Chem. C, 2011, 115 (27), pp 13420-13428. 


\section{ABSTRACT}

A new strategy for oriented covalent immobilization of Trametes hirsuta laccase on gold electrodes is presented. The strategy is based on the gold surface modification with a mixed monolayer of an aromatic diazonium salt derivative and 6-mercapto-1-hexanol for further use as scaffold for the enzyme's covalent linkage. This strategy offers a variety of advantages such as high stability and laccase-friendly support morphology, which turns it into a suitable metal-enzyme interface. Conditions aiming at optimum orientation for direct electron transfer (DET) via the T1 copper site were studied. Current density values up to $40 \mu \mathrm{A} \cdot \mathrm{cm}^{-2}$ were measured for the electrocatalytic reduction of $\mathrm{O}_{2}$ in absence of redox mediators. This strategy is a big step forward in the development of laccase-modified gold electrodes for bioelectrocatalytic reduction of $\mathrm{O}_{2}$.

KEYWORDS: Laccase, Gold, Biocathode, Diazonium salt, direct electron transfer.

\section{Introduction}

As the starvation of traditional fuel sources approaches, alternative sources of sustainable electrical energy, e.g. biofuel cells, have become a strategic research field. ${ }^{[1]}$ Biofuel cells comprise two electrodes designed to harvest electric current from bioelectrocatalyzed chemical redox transformations. One of these electrodes is responsible for the oxidation of the fuel, typically hydrogen ${ }^{[2]}$ or organic compounds, ${ }^{[3]}$ while another electrode is responsible for the reduction of an oxidant, e.g. $\mathrm{O}_{2} \cdot{ }^{[4]}$ These redox reactions are biocatalyzed by different enzymes ${ }^{[5]}$ and can occur directly at the electrodes or generating appropriate redox substrates from raw matter. Over the last two decades most of the technical challenges have been focused to develop suitable interfaces able to link the biochemical processes to the electrochemical ones, thus improving the charge transport between the biocatalysts and the electrodes. ${ }^{[6]}$ Many efforts aimed at the optimization of a biocatalytic anode suitable for biofuel cells ${ }^{[7]}$ However, 
although there are several reported examples for biofuel cell cathodes,${ }^{[8]}$ further development towards higher efficiency is still required.

Reduction of $\mathrm{O}_{2}$ to $\mathrm{H}_{2} \mathrm{O}$ is the most efficient reaction at the cathode for accepting the electrons produced at the anode. This reaction can be catalyzed by enzymes such as copper-containing oxidases. ${ }^{[9]}$ Laccases are blue multicopper oxidases that catalyze the oxidation of many poly-substituted benzene derivatives, lignins, and inorganic complexes with concomitant reduction of $\mathrm{O}_{2}$ to $\mathrm{H}_{2} \mathrm{O}^{[10]}$ The active site of laccase comprises four copper ions, which are classified according to their Electronic Paramagnetic Resonance (EPR) signals as the T1 copper and a trinuclear cluster consisting on a T2 copper ion and two T3 copper ions. The T1 copper ion and T2/T3 copper cluster are connected through a histidine-cysteine bridge allowing intramolecular electron transfer.$^{[9,10]} \mathrm{T} 1$ copper is recognized as the enzyme site for substrate oxidation, and the T2/T3 cluster as the oxygen-reduction site. The redox potential of the $\mathrm{T} 1$ copper ion ranges approximately from 800 to $300 \mathrm{mV} v s$. NHE for different laccases,${ }^{[9]}$ e.g. Trametes hirsuta laccase has a potential of $780 \mathrm{mV}$ (measured at $\left.\mathrm{pH} 6.0\right) .^{[11]}$

Significant efforts have focused on developing a suitable electric connection between electrodes and laccases. There are two main targets for optimizing a laccase cathode: $(i)$ to obtain the highest possible potential for $\mathrm{O}_{2}$ electroreduction and (ii) to produce the most intense current density of the device. The first goal requires an immobilization method that allows the enzyme to transfer the electrons directly (direct electron transfer, DET) from the electrode to $\mathrm{O}_{2}$ molecules using its biological T1-to-T2/T3 path, thus avoiding a mediated electron transfer (MET) bioelectrocatalysis. When DET is not efficient and a mediator is needed an undesired decrease of the $\mathrm{O}_{2}$ reduction's potential occurs. Maximization of the current output requires dense biocatalyst packing on the electrode surface, oriented in such a way that DET mechanism is favorable.

Carbon electrodes have shown to be a very suitable electroactive surface for laccase accomodation..$^{[9,12,13]}$ T1-to-surface is the statistically preferred orientation by adsorption of the enzyme on a bare graphite electrode. ${ }^{[9,13]}$ However, physical adsorption results in low stability of the enzyme on the electrode, thus a stronger linkage is required for biofuel cell applications. At least two different 
approaches have shown to be successful for the proper immobilization of laccases on carbon surfaces.

One of them is based on entrapping laccases into polyelectrolytes or hydrogels loaded with a redox mediator. ${ }^{[8,12]}$ The use of polymeric structures allows a higher concentration of enzyme on the electroactive surface, but the effective potential is depleted due to the presence of a mediator and the background current is increased. Another approach consists on chemical modification of the electrodes surfaces for favoring specific interactions with the laccase molecules and their oriented immobilization. ${ }^{[14]}$

Due to its mechanical stability, high electrical conductivity, and chemical resistance gold is a rather interesting material for bioelectronic devices. Besides, new nano-structured gold materials potentially interesting as supporting interfaces for these applications are currently being developed. ${ }^{[15-17]}$ Nevertheless, the attempts to immobilize laccase on a gold surface for DET-based bioelectrocatalysis have not been as successful as on graphite. ${ }^{[9]}$ Physical adsorption on gold yields high denaturalization of the enzyme, whereas the use of self-assembled monolayers (SAMs) results in $\mathrm{O}_{2}$ electroreduction to $\mathrm{H}_{2} \mathrm{O}_{2} \cdot{ }^{[18]}$ Moreover, the catalytic current densities achieved on gold electrodes even with the usage of redox mediators were much smaller compared to the DET-based laccase-modified carbon electrodes. ${ }^{[15,}$ 19]

In this work we show that a diazotation strategy for the modification of gold electrodes for further laccase covalent immobilization results in very-well pronounced DET-based bioelectrocatalysis. Diazonium salts are very well known compounds for the modification of carbon surfaces, ${ }^{[2,13,20]}$ although seldom used on gold. ${ }^{[21,22]}$ To our best knowledge, this strategy has never been used for the immobilization of laccase on gold and there are only few reports where similar procedure was used to immobilize the enzyme horseradish peroxidase. ${ }^{[23,24]}$

\section{Materials and Methods}

Enzyme. Trametes hirsuta laccase from the basidiomycete, strain T. hirsuta 56, was obtained from the laboratory collection of the Moscow State University of Engineering Ecology following the 
purification procedure previously reported. ${ }^{[1]}$ The enzyme was homogeneous as judged from SDSPAGE and HPLC. The highly concentrated preparations of T. hirsuta laccase were stored in $0.1 \mathrm{M}$ phosphate buffer, $\mathrm{pH} 6.5$, at $-20^{\circ} \mathrm{C}$. The concentration of the enzyme in stock solution was measured using BIO-RAD (Bio-Rad Laboratories) according to the Bradford method. ${ }^{[25]}$ The calibration curve was done using bovine serum albumin (BSA) as the protein standard. The catalytic turnover of the enzyme was measured spectrophotometrically using $1 \mathrm{mM}$ 2,2'-azinobis-(3-ethylbenzothiazoline-6-sulfonic acid) diammonium salt (ABTS) as substrate and its value was $397 \mathrm{~s}^{-1}$, which is in good agreement with previously measured maximal catalytic constants of $T$. hirsuta laccase towards different substrates. ${ }^{[1]}$

Reagents. All reagents were purchased on ACS purity grade. Gold disc electrodes (5 mm diameter, 99.999\% purity) were purchased from Pine Instruments. Gold-covered wafers $\left(1 \mathrm{x} 1 \mathrm{~cm}^{2}\right)$ used for AFM were purchased from Metallhandel Schroer GMBH. p-nitrophenyldiazonium salt, 1-(3dimethylaminopropyl)-3-ethylcarbodiimide (EDC), N-hydroxysuccinimide (NHS), 6-mercapto-1hexanol $(\mathrm{MH}), 30 \% \mathrm{H}_{2} \mathrm{O}_{2}$, Sodium Perchlorate, $\mathrm{BF}_{4} \mathrm{ClO}_{4}$, MES hydrate $99.5 \%$, ABTS and $\mathrm{K}_{4}\left[\mathrm{Fe}(\mathrm{CN})_{6}\right]$ were purchased from Sigma-Aldrich. $\mathrm{NaOH}, 98 \% \mathrm{H}_{2} \mathrm{SO}_{4}$, absolute $\mathrm{EtOH}$, acetic acid 96\%, sodium $m$ peryodate and acetonitrile HPLC grade were purchased from Panreac. Alumina slurry $0.05 \mu \mathrm{m}$ size was purchased from Buehler. Acetonitrile was made anhydrous prior to use with molecular sieves (SigmaAldrich), whereas all other regents were used as received. All aqueous solutions were prepared in deionized water (Milli-Q grade, Millipore).

Gold surface cleaning. Au coated substrates $\left(1 \mathrm{x} 1 \mathrm{~cm}^{2}\right)$ were purchased from Metallhandel Schroer GMBH. They consist of $200 \mathrm{~nm}$ gold over $1-4 \mathrm{~nm}$ chromium prepared on borosilicate glass. The substrates were cleaned with "piranha" solution $\left(3 \mathrm{H}_{2} \mathrm{SO}_{4} 98 \%: 1 \mathrm{H}_{2} \mathrm{O}_{2} 30 \%\right)$ for 2 minutes and rinsed extensively with water, and later with ethanol (CAUTION, Piranha solution is specially dangerous, corrosive and may explode if contained in a closed vessel, it should be handled wih special care). The substrates were then annealed to an orange glow for a few seconds in a propane flame (this operation was repeated 4 times). This treatment is known to produce $\mathrm{Au}$ (111) grains showing atomically flat surfaces up to a few $\mu \mathrm{m}$ radious size, suitable for atomic force microscopy (AFM). 
Inmediately after cleaning the gold substrates they were used for the modification process described below.

Gold disc electrodes cannot be flamed because they are socketed in a Teflon ${ }^{\circledR}$ holder, so they were cleaned using a different protocol. The gold disc electrodes were cleaned by immersion in "Piranha" solution during $30 \mathrm{~min}$, and then they were gently rinsed with water, and polished against alumina slurry $0.05 \mu \mathrm{m}$ size during $3 \mathrm{~min}$. After rinsing the gold surface, it was immersed into $\mathrm{EtOH} / \mathrm{H}_{2} \mathrm{O} 2: 1$ solution and taken into an ultrasonic bath during ten minutes. Later the surface was cleaned by 25 electrochemical reductive cyclic voltammograms ranging the potential from 0 to $-1.5 \mathrm{~V}(v s . \mathrm{Ag} / \mathrm{AgCl})$ using $200 \mathrm{mV} \cdot \mathrm{s}^{-1}$ scan rate in $0.5 \mathrm{M} \mathrm{NaOH}$ solution. Afterwards, the electrode was activated by oxidative cyclic voltammetry in $0.1 \mathrm{M} \mathrm{H}_{2} \mathrm{SO}_{4}$ from 0 to $1.5 \mathrm{~V}$ at $100 \mathrm{mV} \cdot \mathrm{s}^{-1}$ scan rate 25 times.

Gold surface modification. The gold electrodes were immersed in a solution of acetonitrile containing $2 \mathrm{mM}$ p-nitrophenyldiazonium salt and $100 \mathrm{mM} \mathrm{BF}_{4} \mathrm{ClO}_{4}$. One cyclic voltammogram from $0.6 \mathrm{~V}$ to -0.6 V with $200 \mathrm{mV} \cdot \mathrm{s}^{-1}$ scan rate was recorded for each gold electrode. Afterwards the gold surfaces were taken into an EtOH- $\mathrm{H}_{2} \mathrm{O}$ 9:1, $0.1 \mathrm{M} \mathrm{KCl}$ solution, and an electrochemical modification was carried out running a reductive cyclic voltammogram from 0 to $-1.4 \mathrm{~V}$ using $100 \mathrm{mV} \cdot \mathrm{s}^{-1}$ scan rate. The aminoterminated modified electrodes were then immersed overnight in a water solution containing $1 \mathrm{mM} \mathrm{MH}$.

Covalent immobilization of laccase onto gold electrodes. $5 \mu \mathrm{L}$ of Trametes hirsuta laccase were placed into $55 \mu \mathrm{L}$ of $10 \mathrm{mg} \cdot \mathrm{mL}^{-1} \mathrm{NaIO}_{4}$ solution during $30 \mathrm{~min}$. Afterwards $90 \mu \mathrm{L}$ of $100 \mathrm{mM} \mathrm{Na}_{2} \mathrm{HPO}_{4}$ were added to the solution to obtain $\mathrm{pH}$ 7. The modified gold electrode was then incubated in the enzyme solution during $90 \mathrm{~min}$. The enzyme-modified gold electrodes were rinsed with $10 \mathrm{mM}$ MES buffer, $\mathrm{pH}$ 6.0. The electrode surface was covered with $10 \mu 1$ of $10 \mathrm{mM}$ MES pH 6.0 buffer solution containing $36 \mathrm{mM}$ EDC and $17 \mathrm{mM}$ NHS and tapped to avoid evaporation, letting the reaction to take place for 2 hours. Control experiments were performed by incubating directly the modified gold electrode in the EDC and NHS solution containing laccase that had not been oxidized with periodate.

Electrochemical measurements. Electrochemical experiments were performed with an Autolab PGSTAT30 analyzer controlled by GPES 4.9 software (Eco Chemie, The Netherlands). Experiments 
were run in a three-electrode glass cell using a $\mathrm{BAS} \mathrm{Ag} / \mathrm{AgCl}$ reference electrode $(210 \mathrm{mV} v s$. NHE) and a platinum wire counter electrode. The cell temperature was controlled by a thermostated water jacket. All redox potentials mentioned in the text and figures are given $v s$. $\mathrm{Ag} / \mathrm{AgCl}$ reference electrode. The gold-covered wafer was directly connected to the potentiostat. The gold disc electrode was connected to a MSR electrode rotator from Pine Instruments. The Faradaic impedance spectra were recorded using a FRA 4.9 software (Eco Chemie, The Netherlands) while applying $0.3 \mathrm{~V}$ bias potential and using $10 \mathrm{mV}$ alternative voltage in the frequency range $100 \mathrm{mHz}-10 \mathrm{kHz}$. As electrochemical probe $0.1 \mathrm{mM} \mathrm{K}_{4}\left[\mathrm{Fe}(\mathrm{CN})_{6}\right]$ was used. The experimental impedance spectra were fitted using electronic equivalent circuits (Randles and Ershler model) in order to derive the electron-transfer resistance, $R_{\mathrm{et}}$, values. For this purpose, commercial software (ZView, version 2.1b, Scribner Associates, Inc.) was exploited.

AFM microscopy. Atomic force microscopy (AFM) studies were performed with an Agilent 5500 microscope operating in tapping mode in liquid medium. Olympus cantilevers (RC800PSA, 200_20 $\mathrm{mm}$ ) with a tip-radius of $c a .20 \mathrm{~nm}$ and spring constants of $0.15-0.6 \mathrm{~N} / \mathrm{m}$ were used.

XPS analysis. Surface elemental analysis by means of X-ray photoelectron spectroscopy (XPS) was carried out using a SPECS GmbH spectrometer operating in the constant analyzer energy mode. A nonmonochromatic magnesium X-ray source $(1253.6 \mathrm{eV})$ was used with power of $100 \mathrm{~W}$ and voltage of 10 $\mathrm{kV}$. Samples were stuck with a double-sided adhesive conductive carbon tapes on sample holders. The instrument operated typically at pressures near $8 \cdot 10^{-9}$ mbar in the analysis chamber. Pass energies of 75 and $25 \mathrm{eV}$ were used for acquiring both survey and high-resolution spectra, respectively. Survey data were acquired from kinetic energy of 1254 to $200 \mathrm{eV}$ with an energy step of $1 \mathrm{eV}$ and $100 \mathrm{~ms}$ dwell time per point. The high resolution scans were taken around the emission lines of interest using $0.1 \mathrm{eV}$ steps and $100 \mathrm{~ms}$ dwell time per point. SpecsLab Version 2.48 software was used for spectrometer control and data handling. The energetic position of the $A u 4 f_{7 / 2}$ emission line of the gold film on the substrate (binding energy of $84.0 \mathrm{eV}$ ) was used to calibrate the energy scale of the spectra. 


\section{Results}

\section{Gold surface functionalization}

Gold electrodes were prepared to serve as scaffold for the build-up of a functionalized organic nanolayer. The electrodes were carefully prepared as described in the previous section. Electroactive area of the rotating disc gold electrodes was obtained by integrating the gold oxide reduction peak measured by cyclic voltammetry ${ }^{[26]}$ and found to be $0.47 \mathrm{~cm}^{2}$ (Supplementary Material, Figure S1). The gold disc electrode was $5 \mathrm{~mm}$ in diameter yielding a geometric area of $0.196 \mathrm{~cm}^{2}$ with the calculated roughness factor of about 2.4. However, following the existing consensus for enzyme-modified graphite electrodes, the current densities were determined using the geometric (projected) electrode area.

The modification of the gold surface was carried out following the strategy described in Scheme 1. The gold electrode was firstly modified with $p$-nitrophenyl groups by application of a single cyclic voltammetry from +0.6 to $-0.6 \mathrm{~V}$ at $200 \mathrm{mV} \cdot \mathrm{s}^{-1}$ in presence of $p$-nitrophenyldiazonium salt (Supplementary Information, Figure S2). The voltammogram shows two characteristic reduction peaks at +385 and $+200 \mathrm{mV}$ attributed to the reduction of the diazonium salt on different planar gold surfaces. ${ }^{[27]}$ The reduction yields a strong Au-C bond that does not oxidize back in this potential range. In the second step the nitro groups were electrochemically reduced to amino and hydroxylamine groups by performing two cyclic voltammograms from 0 to $-1.4 \mathrm{~V}$ vs. $\mathrm{Ag} / \mathrm{AgCl}$ in $\mathrm{H}_{2} \mathrm{O}-\mathrm{EtOH}$ 9:1 solution (Supplementary Information, Figure S3). The first cyclic voltammogram shows the irreversible reduction of nitro groups to amino and hydroxylamino groups as a broad electrochemical wave ranging from -500 to $-1200 \mathrm{mV}$ and centered at $-820 \mathrm{mV}$. The second cycle shows the reversible oxidation of hydroxylamine groups to nitroso groups at $-265 \mathrm{mV} \cdot{ }^{[28]}$ Integration of the nitro groups reduction wave allows to estimate the coverage of phenyl groups on the gold electrode as $5.5 \times 10^{-10} \mathrm{~mole} \cdot \mathrm{cm}^{-2}$, which is approximately $45 \%$ of the theoretical maximum monolayer coverage $\left(12 \times 10^{-10}\right.$ mole $\left.\cdot \mathrm{cm}^{-2}\right) \cdot{ }^{[29]}$ As the electrochemical reduction of diazonium salts on the gold surface does not yield a complete monolayercoverage under the conditions used in this work, the gold was incubated overnight in a thiol solution for SAM formation over the naked regions. Positively charged (cystamine), negatively charged (mercapto 
propionic acid) and uncharged hydrophilic (6-mercapto-1-hexanol, $\mathrm{MH}$ ) thiols were tested as blotting compounds; non-blotted electrodes showing only the partial coverage provided by the diazonium salt reaction were also tested. By far the best results for further covalent modification of the electrode with laccase, in terms of bioelectocatalytic current obtained, were the ones obtained with MH. Although the manuscript focus on $\mathrm{MH}$ results, cyclic voltammetry experiments including a non-blotted electrode together with either cystamine or mercaptopropionic acid blotted electrodes are shown in the supplementary information (Table S2). The mixed amino-aryl- and $\mathrm{MH}$ - modified gold surface was characterized by electrochemical desorption, Electrochemical Impedance Spectroscopy (EIS), AFM microscopy and XPS spectroscopy as follows.

\section{Electrochemical desorption of MH SAM}

The electrode modified with $p$-aminophenyl and $\mathrm{MH}$ was immersed in an electrochemical cell containing $0.5 \mathrm{M} \mathrm{NaOH}$ aqueous solution. After bubbling with $\mathrm{N}_{2}$ for $15 \mathrm{~min}$, a reductive cyclic voltammogram was scanned from 0 to $-1.3 \mathrm{~V}$ (Figure S5). The integration for the thiol reduction waves that range from $-1 \mathrm{~V}$ to $-1.2 \mathrm{~V}$ allows calculating a thiol coverage on the gold electrode of $6.7 \times 10^{-10}$ mole $\cdot \mathrm{cm}^{-2}$. The same electrode modified only with $\mathrm{MH}$ gave a coverage of $9.1 \times 10^{-10} \mathrm{~mole} \cdot \mathrm{cm}^{-2}$, which is very similar to the expected coverage for a gold electrode modified only with a single monolayer of an alkanethiol, $9.3 \times 10^{-10}$ mole $\cdot \mathrm{cm}^{-2}{ }^{[30]}$ The difference of thiol coverage between the pure $\mathrm{MH}$ and the mixed monolayers was $c a$. $27 \%$. This value is attributed to the presence of the phenyl molecules chemically bound to the surface in the mixed monolayer. The divergence between the $27 \%$ of surface area estimated by thiol desorption and the $45 \%$ coverage estimated previously by the $p$-nitrophenyl reduction step suggests the existence of more than one layer of aryl groups in some regions of the electrode.

\section{Impedance spectroscopy}

EIS was used to characterize the modified electrodes. Measurements for three different stages of the gold modification were performed using $0.3 \mathrm{~V}$ bias potential with $\mathrm{K}_{4}\left[\mathrm{Fe}\left(\mathrm{CN}_{6}\right)\right]$ as electrochemical probe dissolved in $10 \mathrm{mM}$ acetate buffer $\mathrm{pH} 4.2$ with $100 \mathrm{mM} \mathrm{NaClO}_{4}$. A comparison of $p$-nitrophenyl, $p$ - 
aminophenyl and p-aminophenyl $+\mathrm{MH}$ modified electrodes is shown in Figure 1A. The surface modified with nitrophenyl groups gave a resistance for electron transfer $\left(\mathrm{R}_{\mathrm{et}}\right)$ of $c a .55 \mathrm{k} \Omega$. This high value for $\mathrm{R}_{\mathrm{et}}$ is expected because the gold surface contains plenty of negatively polarized nitro groups, which repels a negatively charged probe such as ferrocyanide. The gold surface modified with amino groups showed a $\mathrm{R}_{\mathrm{et}}$ of $c a .5 .4 \mathrm{k} \Omega$. The $\mathrm{R}_{\mathrm{et}}$ decreased one order of magnitude when compared with the p-nitrophenyl modified surface. This result was also expected because the amino groups are protonated at acidic $\mathrm{pH}$, therefore positively charged and attractive for the electrochemical probe. The $p$ aminoaphenyl + $\mathrm{MH}$ modified gold surface showed a $\mathrm{R}_{\mathrm{et}}$ value of $c a .9 \mathrm{k} \Omega$, a 2-fold increase compared to $p$-aminophenyl modified electrode. $\mathrm{MH}$ should cover the surface areas where diazotation did not occur and remove the non-chemically bonded aromatic groups without perturbing the Au-C covalently bonded amino phenyl groups. ${ }^{[31]}$ Therefore, the effect of $\mathrm{MH}$ on the increase $\mathrm{R}_{\mathrm{et}}$ was attributed to the blotting of naked gold regions.

Control impedance spectroscopy studies of a bare gold electrode and an electrode modified only with MH were performed (Figure $1 \mathrm{~B}$ ). The $\mathrm{R}_{\mathrm{et}}$ shown by the bare gold in this frequency range was negligible, where only a typical Warburgh mass-transport controlled process was observed. On the other hand, the MH-modified electrode showed the characteristic semicircle in the Nyquist representation, where the $\mathrm{R}_{\mathrm{et}}$ was $8 \mathrm{k} \Omega$. This value is comparable to the value obtained for the $p$-aminophenyl $+\mathrm{MH}$ modified electrode.

\section{XPS Spectroscopy}

XPS measurements were carried out to confirm the existence of a nanolayer containing both $p$ aminophenyl and $\mathrm{MH}$ groups. Figure 2A shows the core spectra for the $\mathrm{N} 1 \mathrm{~s}$ region, which shows a characteristic signal at $399.5 \mathrm{eV} \cdot{ }^{[2 \mathrm{c}]}$ It is clearly seen that the mixed-nanolayer electrode shows the same signal as the control electrode, which is grafted only with the $p$-aminophenyl derivatives while the electrode modified only with a MH SAM shows no response to this energy. Figure $2 \mathrm{~B}$ shows the $\mathrm{S} 2 \mathrm{p}$ region, which appears mainly as two peaks centered at 162 and $163.1 \mathrm{eV}$, which are due to the duplet $\mathrm{S}$ 
$\mathrm{p} 1 / 2$ and $\mathrm{S} \mathrm{p} 3 / 2 .{ }^{[32]}$ As it happens in the $\mathrm{N} 1 \mathrm{~s}$ region, it is clearly seen that the mixed nanolayers contains the signal equivalent to the pure-MH modified electrode, thus indicating the presence of a MH-modified region in the mixed nanolayer electrode. The $p$-aminophenyl modified electrode, which does not contain any thiol derivative, shows no response at these binding energy levels. This experiment confirms the coexistence of both species in the mixed-nanolayer electrode. As the grafting layer is nearly a monolayer, the contribution of adsorbed species such as $\mathrm{CO}_{2}, \mathrm{~N}_{2}$, etc. to the absolute signals is significant, distortioning the comparison of the monolayer atoms and poisoning any possible cuantitative analysis. Other XPS information can be found in the supplementary information: the survey spectra, the core Au 4f spectra where is shown the decrease in the intensity of Au 4f7/2 (84 eV) and Au 4f5/2 (88 eV) when the electrode is modified, and the core C 1s spectra.

\section{Covalent immobilization of laccase}

The $p$-aminophenyl-MH modified gold surface represents a suitable scaffold for the covalent immobilization of laccase. The enzyme was incubated with a mild oxidizer, $\mathrm{NaIO}_{4}$, thus opening the glycosilated residues existing on the enzyme surface and exposing aldehyde groups. ${ }^{[18]}$ The functionalized gold electrode's aminophenyl groups allowed the enzyme to react with them forming Schiff's bases. Once the enzyme was bound to the surface, EDC and NHS were deposited onto the electrode surface. These chemicals activated the carboxylate groups present in the laccase surface to form amide bonds with the amino-modified electrode surface. Following this step-wise strategy an oriented and stable immobilization of the laccase was expected (Scheme 1).

The covalent immobilization of laccase onto the modified gold electrode was studied by means of AFM. Figure 3A shows a topographic AFM image of a gold $(1,1,1)$ surface after the laccase immobilization procedure. The typical gold $(1,1,1)$ structure could still be observed after immobilization, i.e. relatively flat grains of few microns separated by deep boundaries. By zooming into one of those grains it could be observed that the surface was decorated with a film composed of globules and holes randomly distributed along the surface (Figures 3B and 3D). The root mean square rugosity of the sample, $R_{\mathrm{q}}$, was about 3-4 $\mathrm{nm}$. This value is consistent with the presence of a monolayer of laccase 
molecules $\left(65 \times 55 \times 45 \AA^{3}\right),{ }^{[33]}$ because the laccase molecules stand close to each other and the AFM tip could not define the entire molecule topography, lowering $R_{q}$ value. However, the presence of holes randomly distributed across the sample with heights close to the laccase larger diameter points suggests the presence of a sub-monolayer of laccase molecules rather than a complete monolayer. Figure $3 \mathrm{C}$ depicts a transversal topographic profile showing globule lateral sizes varying from $40 \mathrm{~nm}$ to over 100 $\mathrm{nm}$. This dispersion in both lateral size and height, which ranged from $1 \mathrm{~nm}$ up to $7 \mathrm{~nm}$, suggests that the enzyme was organized in little compact islands separated by enzyme-free boundaries of a few tenths of $\mathrm{nm}$. This non-continous disposition of the enzymes resembles the aminophenyl-MH mixed monolayer distribution (Supporting Information, Figure S6).

It should be noted that although vertical resolution of AFM is about $0.3 \mathrm{~nm}$, lateral resolution is given by the tip convolution (which radius ranges from 20 to $40 \mathrm{~nm}$ ). Thus, a globule with lateral dimensions in the mentioned range contains an uncertain number of laccase molecules. This limitation in the AFM tip makes impossible an accurate surface laccase coverage calculus on the gold electrode based only on the AFM study.

Control measurements where done with a naked gold $(1,1,1)$ surface (Supporting Information, Figure S6A) and after its functionalization with aminophenyl groups together with the MH SAM (Supplementary Information, Figure S6B), which showed much smoother topographic profiles (Supplementary Information, Figure S6D) compared to the laccase immobilized gold surface (Supplementary Information, Figure S6C). Moreover, Figure S6B clearly shows two distinct heigths, a result compatible with the presence of a mixed monolayer of aminophenyl groups and MH SAM.

\section{Bioelectrocatalytic reduction of oxygen}

The DET provided by a laccase rotating electrode was evaluated by measuring the electrocatalytic reduction of $\mathrm{O}_{2}$ in $10 \mathrm{mM}$ acetate buffer, $\mathrm{pH} 4.2$ with $100 \mathrm{mM} \mathrm{NaClO}$. Figure 4A shows the electrochemical response with different rotation rates under air-saturated conditions. A clear electrocatalytic effect due to $\mathrm{O}_{2}$ reduction was observed at potentials below $650 \mathrm{mV}$ when comparing cyclic voltammograms of electrodes with and without immobilized laccase. As can be seen in Figure 4A 
rotation increased the mass-transfer of $\mathrm{O}_{2}$ to the electrode providing a $33 \%$ enhancement in current for the plateau-reaching potential. The current density for a motionless system was $-10.5 \mu \mathrm{A} \cdot \mathrm{cm}^{2}$, whereas for the electrode rotated at 2,500 rpm the current density increased up to $-14 \mu \mathrm{A} \cdot \mathrm{cm}^{2}$. Rotation also provides a sharper current increase at $650 \mathrm{mV}$ due to the stirring and the difussion-minimization effects. The inset in Figure 4A shows the current density measured at $200 \mathrm{mV}$ for different rotation rates showing that the electrode does not reach a complete plateau even at 2,500 rpm.

Figure 4B shows the performance of the laccase-modified electrode immersed into an $\mathrm{O}_{2}$-saturated buffer solution. Under $\mathrm{O}_{2}$ saturation conditions the current density gains a 3-fold increase. Even for nonrotation conditions the onset for $\mathrm{O}_{2}$ reduction is practically as sharp as for the case of 2,500 rpm. Nevertheless, during the measurement some depletion of $\mathrm{O}_{2}$ occurs, which is proved by the increase in the electrode performance observed when the electrode was rotated at 1,500 rpm. Higher rotation rates do not provide a higher current response (Fig. 4B, inset) and the voltammograms do not reach a limiting current at low potentials. Both effects suggest that under these conditions the limiting step in the bioelectrocatalytic $\mathrm{O}_{2}$ reduction is, in all likelihood, the rate of DET between the T1 site of the laccase and the electrode.

Electrocatalytic currents of $\mathrm{O}_{2}$ reduction were also measured by mediated electron transfer (MET) using the redox mediator ABTS $0.1 \mathrm{mM}$, as demonstrated in Figure 5A. When comparing the cyclic voltammograms in presence and in absence of ABTS it could be observed that their shapes were quite similar. Under MET regime the voltammogram looks slightly more sigmoidal and a plateau current is not reached. The current density measured under $\mathrm{O}_{2}$ saturation at $1000 \mathrm{rpm}$ and $+200 \mathrm{mV}$ conditions is only $20 \%$ higher for MET than the current provided by DET. Under these conditions the catalytic current by MET also was almost independent of mass transfer (not shown).

To prove that efficient DET of laccase requires an orientation strategy via two-step covalent bonding, control experiments consisting of immobilizing the enzyme directly by carbodiimide coupling were performed. In this case, a non-periodate-oxidized laccase solution was immobilized, avoiding the Schiff's base formation. The bioelectrocatalytic response by DET in this case yielded no significative 
current increase relative to the cyclic voltammogram given by a modified electrode before the laccase bonding (Figure 5B). When measuring MET-based bioelectroreduction of $\mathrm{O}_{2}$ using ABTS a 6-fold increase occurred in the electrocatalytic current, thus showing that active laccase was attached to the electrode surface but was unable to take directly electrons from the gold electrode to reduce $\mathrm{O}_{2}$.

The stability of the catalytic current provided by laccase-modified electrodes using the two-step strategy was measured during 33 hours with constant $\mathrm{O}_{2}$ supply and $500 \mathrm{rpm}$ rotation (Figure 6). After one day of continuous operation the electrode was still keeping $70 \%$ of its initial bioelectocatalytic response.

Control cyclic voltammetry and differential pulse voltammetry measurements of laccase-modified electrodes in absence of $\mathrm{O}_{2}$ were recorded. However, no clear peaks that could be attributed to any of the $\mathrm{Cu}$ centers of the laccase were observed (data not shown).

\section{Discussion}

The scope of this work has been to develop a strategy for the oriented and stable immobilization of $T$. hirsuta laccase on gold electrodes with the aim of measuring high bioelectrocatalytic currents of $\mathrm{O}_{2}$ reduction based on DET. To achieve this goal it is compulsory to first functionalize the gold electrode in a controlled way, in which specific covalent bonds can be formed with the enzyme that lead to adequate orientation of its $\mathrm{T} 1$ site to the electrode surface for efficient DET reactions. The electrochemical reduction of aryldiazonium salts allows modification of gold surfaces with aromatic rings containing different functional groups. ${ }^{[34,35]}$ This functionalization method is much more robust than the standard self-assembly of a thiol monolayer on gold ${ }^{[35]}$ However, the diazonium salt method may lead to a multilayered film due to aryl radical attack to the already grafted aromatic rings ${ }^{[34]}$ In order to minimize multilayer formation, which is detrimental to DET of attached proteins, we have shortened the electroreduction time of the diazonium salt. Charge quantification of the electrochemical processes and AFM characterization of modified gold are compatible with a submonolayer formation of phenyl groups on the gold electrode. The electrochemically-estimated coverage is approximately $45 \%$ of that expected 
for a compact monolayer, ${ }^{[29]}$ and the rugosity of the modified surface is about 20 times smaller than the one measured with multilayered films (Supplementary Information, Figure S4). ${ }^{[3]}$ As the $p$ aminophenyl coverage on the gold electrodes was substantially below a compact monolayer, we subsequently incubated the electrodes in a $\mathrm{MH}$ solution. $\mathrm{MH}$ brought several benefits to the modified surface. First, it covered the areas not modified with the diazonium salt, avoiding the physical adsorption of laccase, which could cause its denaturation and would lower the redox potential of $\mathrm{O}_{2}$ electroreduction. ${ }^{[9]}$ Second, $\mathrm{MH}$ would also clean the surface by removing any organic residues physically adsorbed on the electrode. ${ }^{[31]}$ Third, the combination in the electrode nanolayer of rigid anchoring groups (aminophenyl rings) with flexible chains ended with a polar functional group (hydroxyl) that can establish hydrogen bonds should aid quite stable immobilization of protein molecules. Formation of a SAM of $\mathrm{MH}$ on the gold surface is shown by the reductive desorption of thiols measured by cyclic voltammetry (Supporting Information, Figure S5). Charge integration of this electrochemical process indicates that $\mathrm{MH}$ had covered the naked gold surface left after the modification step with the diazonium derivative. The impedance spectroscopy studies and XPS measurements also confirmed the existence of an aminophenyl-MH mixed monolayer on the electrode surface. It should be noted that cuantitative analysis from XPS data was not performed because of the adsorbed species on the electrode devirtuates the ratio $\mathrm{C}-\mathrm{S}$ and $\mathrm{C}-\mathrm{N}$ expected from an ideal modified electrode.

Evidence of the laccase immobilization on the gold electrode was obtained from AFM characterization and from the measurement of high electrocatalytic currents of $\mathrm{O}_{2}$ reduction. The AFM images suggest that a sub-monolayer of laccase molecules was attached to the gold electrodes, in agreement with an immobilization process controlled by specific covalent bonds. In contrast, AFM images reported by Gonzalez Arzola et al. of non-specific adsorption of a laccase to bare gold surfaces showed a more compact immobilization of enzyme molecules. ${ }^{[19]}$

The high electrocatalytic currents of $\mathrm{O}_{2}$ reduction measured by cyclic voltammetry in the present work indicate that the immobilized laccase molecules were active. Non-turnover signals due to the $\mathrm{Cu}$ centers of laccase were not clearly detected electrochemically, which is in agreement with the 
submonolayer coverage observed by AFM. Generally, it is very difficult to detect non-catalytic signals of redox enzyme coverages below 3-4 $\mathrm{pmol} \cdot \mathrm{cm}^{-2} \cdot{ }^{36,37]}$ In our studies the onset of the catalytic waves for oxygen reduction start at $650 \mathrm{mV}$ vs. $\mathrm{Ag} / \mathrm{AgCl}$, which is in good agreement with previous works on laccase-modified graphite electrodes. ${ }^{[14]}$ Analyzing data from literature it can be clearly stated that the two-step strategy for the T. hirsuta laccase immobilization on gold promotes optimal orientation of immobilized laccase for DET between the $\mathrm{T} 1 \mathrm{Cu}$ site of the enzyme and the electrode leading to 4electron reduction of $\mathrm{O}_{2}$ to $\mathrm{H}_{2} \mathrm{O}$. Most investigations of laccase-modified gold electrodes have been either done using low redox potential laccases,${ }^{[18 b, 38]}$ or the bioelectrocatalysis was observed at much lower potentials than expected for high redox potential enzymes, ${ }^{[18 \mathrm{~b}, 39]}$ possibly because of the degradation of the enzyme or/and its improper orientation, allowing the electrons to be directly transferred to the T2/T3 cluster of the enzyme ${ }^{[9]}$ and yielding partial reduction of $\mathrm{O}_{2}$ to $\mathrm{H}_{2} \mathrm{O}_{2}{ }^{[18 \mathrm{a}]}$ Only one recent article, published while writing this work, has reported DET-based bioelectrocatalytic reduction of $\mathrm{O}_{2}$ at high potentials with a laccase adsorbed onto a gold electrode modified with an anthracene-2-methanethiol SAM. ${ }^{[40]}$

Based on the widely held mechanism of the bioelectrocatalytic reduction of $\mathrm{O}_{2}$ by laccases, namely electron donation from the electrode to the $\mathrm{T} 1$ site of the enzyme, intramolecular electron transfer from the $\mathrm{T} 1$ site to the $\mathrm{T} 2 / \mathrm{T} 3$ cluster, and $\mathrm{O}_{2}$ reduction by the $\mathrm{Cu}$ cluster, ${ }^{[13]}$ three main steps can generally determine the maximum rate with which $\mathrm{O}_{2}$ is reduced on laccase-modified electrodes: the DET reaction (in this case the catalytic current will be equal to the DET limiting current, Eq. 1), the biochemical reduction of $\mathrm{O}_{2}$ within the enzyme (Eq. 2), and the diffusion of $\mathrm{O}_{2}$ to the electrode surface (Eq. 3). Previously, a similar mechanism of enzymatic bioelectrocatalysis has been mathematically developed. ${ }^{[41]}$ Under steady state conditions, such a mechanism gives rise to Eq. 4, which is analogous to an expression giving the resultant conductance of a group of resistors connected in series: ${ }^{[4]]}$

$$
\begin{aligned}
& i_{D E T}=n F A \Gamma k_{D E T} \\
& i_{C a t}=n F A \Gamma k_{c a t} C_{O_{2}} /\left(C_{O_{2}}+K_{M}\right) \\
& i_{D i f f}=0.62 n F D^{2 / 3} A \tilde{N}_{\hat{I}_{2}} v^{-1 / 6} \omega^{1 / 2}
\end{aligned}
$$




$$
1 / i=1 / i_{D E T}+1 / i_{C a t}+1 / i_{\text {Diff }}
$$

Here, $i$ is the steady state current (DET-, catalytic-, or diffusion-limited currents, described in Eqs. 1, 2 , and 3, respectively); $\tilde{N}_{\hat{1}_{2}}$ is the bulk concentration of the substrate $\left(1.2 \cdot 10^{-6} \mathrm{~mol} \cdot \mathrm{cm}^{-3}\right.$ of $\mathrm{O}_{2}$ in oxygensaturated solutions); $\Gamma$ is the surface concentration of adsorbed laccase (in $\mathrm{mol} \cdot \mathrm{cm}^{2}$ ); $A$ is the electrode area $\left(\right.$ in $\left.\mathrm{cm}^{2}\right) ; D$ is the diffusion coefficient of $\mathrm{O}_{2}$ in buffer $\left(19 \cdot 10^{-6} \mathrm{~cm}^{2} \cdot \mathrm{s}^{-1}\right) ; v$ is the kinetic viscosity of the solution $\left(0.01 \mathrm{~cm}^{2} \cdot \mathrm{s}^{-1}\right.$ at $25^{\circ} \mathrm{C}$, a typical value for aqueous solutions); and $\omega$ is the angular frequency (in $\mathrm{rad} \cdot \mathrm{s}^{-1}$ ). The fact that the cyclic voltamograms under $\mathrm{O}_{2}$ saturation conditions do not reach a plateau current and that they were unsensitive to the rotation rate, strongly suggests that DET was the ratelimiting step of the electrocatalytic process of $\mathrm{O}_{2}$ reduction when the highest current density of 40 $\mu \mathrm{A} \cdot \mathrm{cm}^{-2}$ was achieved. ${ }^{[42]}$ Indeed, $k_{D E T}$ could be calculated taking into account a submonolayer of laccase coverage on the electrode surface $\left(\Gamma \sim 10^{-12}\right.$ mole $\left.\cdot \mathrm{cm}^{-2}\right)$ being as high as $100 \mathrm{~s}^{-1}$ (Eq. 1). From Eq. 1 it is very obvious that $k_{c a t}>k_{D E T}$, if DET is the limiting step of biocatalytic reactions. Comparing the two values determined in an homogeneous assay and in heterogeneous catalysis, viz. $397 \mathrm{~s}^{-1}$ and $>100 \mathrm{~s}^{-1}$ respectively, as well as taking all previously described arguments into account, it is reasonable to suggest that laccase adsorbed on modified gold electrodes is at least quasi-native and definitely catalytically active.

Comparison of the electrocatalytic currents measured in DET and MET modes allows us to evaluate the efficiency of the two-step specific immobilization strategy for orienting adequately the laccase molecules towards the electrode surface. The mediator allows transport of electrons from the electrode surface to all immobilized active enzyme molecules, even those whose $\mathrm{T} 1$ site is not facing the electrode for DET reactions. Under the MET regimen the shape of voltammograms was more sigmoidal but a plateau current was not reached. Nevertheless, the current density measured under $\mathrm{O}_{2}$ saturation and 1000 rpm conditions at $+200 \mathrm{mV}$ is only $20 \%$ higher by MET compared to DET, which confirms that a high percentage of active immobilized laccase molecules have adequate orientation for DET- 
based bioelectrocatalytic reduction of $\mathrm{O}_{2}$. This preferred orientation during the immobilization can be explained because most of the sugar residues of the laccase, which form bonds with the amino groups on the electrode, are located in regions of the protein surface near the T1 site. ${ }^{[43]}$ In addition, the presence of hydroxyl groups on the electrode nanolayer could also favor adequate orientation of the laccase, as it has been reported for cellobiose dehydrogenase ${ }^{[44]}$ because these enzymes catalyze the oxidation of many substrates with hydroxyl groups.

Contrary, the DET/MET current ratio (at $+200 \mathrm{mV}$ ) is 0.1 , when the laccase was bound only by carbodiimide coupling. Therefore, it can be roughly estimated that attachment by only amido bonds leads to an 7-fold decrease of the percentage of adequately oriented laccase molecules compared to the two-step immobilization method (DET/MET current ratio was 0.8 in this case). This result is probably obtained because most of carboxylic aminoacids on the enzyme surface are placed at the opposite side of the $\mathrm{T} 1$ site of the enzyme, ${ }^{[43]}$ thus favoring attachment of the laccase in a wrong orientation for proper DET reactions. It is also important to emphasize that the catalytic current density in MET mode was enhanced 7-fold when the laccase was immobilized using the two-step strategy instead of the one-step carbodiimide coupling method. This result indicates that the two-step strategy also helps to increase the total amount of active enzyme bound to the electrode surface.

\section{Conclusions}

A new strategy for the immobilization of Trametes hirsuta laccase on gold electrodes is presented. The use of an aryldiazonium salt for its electroreduction on a gold electrode and subsequent selfassembly of a thiol was shown to be a suitable strategy for adding an organic nanolayer appropriate for the covalent linkage of a laccase to the modified electrode. Immobilization conditions were studied and optimized for vectorizing the enzyme orientation on the modified gold for achieving direct electron transfer from the electrode to the final electron acceptor, oxygen. In this way, the amount of adequately oriented immobilized laccase molecules was increased 7-fold. Therefore, the immobilization strategy allows efficient DET via the T1 site of the enzyme with a bioelectrocatalytic current density for oxygen 
reduction of $c a .40 \mu \mathrm{A} \cdot \mathrm{cm}^{-2}$, the highest DET-based current density achieved for laccase-modified gold electrode reported so far.

\section{ACKNOWLEDGMENT}

This work is funded by the European Research Council, project 3D-NanoBioDevice NMP4-SL-2009229255 and the Spanish MICINN, and project CTQ2009-12649. Dr. M. Pita acknowledges the Ramon y Cajal 2009 program from the Spanish MICINN. Dr. D. Olea acknowledges the JAE program from CSIC.

\section{SUPPORTING INFORMATION}

Supporting Information containing cyclic voltammograms for the gold electrode characterization, gold modification with $p$-nitrophenyl diazonium salt, further reduction from nitro to amino groups, and additional AFM images and XPS results can be found at http://pubs.acs.org.

\section{FIGURE CAPTIONS}

Figure 1. EIS represented as a Nyquist plot. (A) Frequency response analyses for (a) nitro-aryl nanolayer on gold, (b) amino-aryl nanolayer on gold, (c) mixed amino-aryl and 6-mercapto-1-hexanol nanolayer. (B) Frequency response analyses for (a) bare and (b) 6-mercapto-1-hexanol monolayer modified gold electrodes.

Figure 2. (A) XPS core spectra for N 1s signal belonging to gold electrodes modified with (a) grafted $p$ aminophenyl, (b) grafted $p$-aminophenyl and a MH SAM, and (c) MH SAM. (B) XPS core spectra for S $2 \mathrm{p}$ signal belonging to gold electrodes modified with (a) grafted $p$-aminophenyl, (b) grafted $p$ aminophenyl and MH SAM, (c) MH SAM. 
Figure 3. (A) AFM topographic image of laccase molecules adsorbed on a gold $(1,1,1)$ surface. (B) AFM topography zoom of the square drawn in (A). (C) AFM topographic image of another area of the sample. (D) Topographic profile across the line drawn in (C).

Figure 4. Bioelectrocatalytic reduction of oxygen measured on a laccase modified gold electrode using a two-step -Schiff base and NHS-EDC- immobilization strategy under (A) air and (B) oxygen saturated conditions. (a) Background current provided by the electrode before laccase immobilization. (b) Bioelectrocatalytic current provided by the laccase-modified electrode without rotation. (c) Same electrode rotating at $500 \mathrm{rpm}$. (d) Same electrode rotating at $2000 \mathrm{rpm}$. Inset: current density measured at $+200 \mathrm{mV}$ vs. the rotation rate. All measurements were performed in $10 \mathrm{mM}$ acetate buffer $\mathrm{pH} 4.2$ with $100 \mathrm{mM}$ sodium perchlorate at $10 \mathrm{mV} \cdot \mathrm{s}^{-1} \mathrm{scan}$ rate.

Figure 5. Bioelectrocatalytic reduction of oxygen carried on a laccase modified gold electrode (A) using a two-step -Schiff base and NHS-EDC- immobilization strategy and (B) direct reduction using NHS-EDC covalent linkage. (a) Background current provided by the electrode before laccase immobilization. (b) Direct electron current measured at $1000 \mathrm{rpm}$ under oxygen saturation. (c) Mediated electron current measured with $0.1 \mathrm{mM}$ at $1000 \mathrm{rpm}$ under oxygen saturation.

Figure 6. Normalized chronoamperometry measured at an applied potential of $+200 \mathrm{mV}$ of a laccasemodified electrode in $10 \mathrm{mM}$ acetate buffer $\mathrm{pH} 4.2$ with $100 \mathrm{mM}$ sodium perchlorate with $500 \mathrm{rpm}$ rotation rate.

\section{SCHEME TITLES}

Scheme 1. Strategy for the modification of gold with an aryldiazonium salt $(\sim 0.7 \mathrm{~nm})$ and $\mathrm{MH}(\sim 1$ $\mathrm{nm}$ ), and further laccase immobilization. 


\section{REFERENCES}

[1] (a) Davis, F.; Higson, S. P. J. Biosens. Bioelectron. 2007, 22, 1224-1235. (b) Bullen, R. A.; Arnot,

T. C.; Lakeman, J. B.; Walsh, F. C. Biosens. Bioelectron. 2006, 21, 2015-2045. (c) Shukla, A. K.; Suresh, P.; Berchmans, S.; Rajendran, A. Curr. Sci. 2004, 87, 455-468.

[2] (a) Rüdiger, O.; Abad, J. M.; Hatchikian, E. C.; Fernandez, V. M.; De Lacey, A. L. J. Am. Chem. Soc. 2005, 127, 16008-16009. (b) Alonso-Lomillo, M. A.; Rüdiger, O.; Maroto-Valiente, A.; Velez, M.; Rodriguez-Ramos, I.; Muñoz, F. J.; Fernandez, V. M.; De Lacey, A. L. Nano Lett. 2007, 7, 1603-1608.

[3] (a) Tasca, F.; Gorton, L.; Harreither, W.; Haltrich, D.; Ludwig, R.; Noll, G. J. Phys. Chem. C 2008, 112, 9956-9961. (b) Tasca, F.; Gorton, L.; Harreither, W.; Haltrich, D.; Ludwig, R.; Noll, G. J. Phys. Chem. C 2008, 112, 13668-13673. (c) Kuwahara, T.; Oshima, K.; Shimomura, M.; Miyauchi, S. J. Appl.Polym. Sci. 2007, 104, 2947-2953.

[4] (a) Kavanagh, P.; Jenkins, P.; Leech, D. Electrochem. Commun. 2008, 10, 970-972. (b) Gallaway, J.; Wheeldon, I.; Rincon, R.; Atanassov, P.; Banta, S.; Barton, S. C. Biosens. Bioelectron. 2008, 23, 1229- 1235. (c) Mano, N.; Soukharev, V.; Heller, A. J. Phys. Chem. B 2006, 110, 11180-11187. (d) Tsujimura, S.; Kano, K.; Ikeda, T. J. Electroanal. Chem. 2005, 576, 113-120.

[5] (a) Cracknell, J. A.; Vincent, K. A.; Armstrong, F. A. Chem. Rev. 2008, 108, 2439-2461. (b) Minteer, S. D.; Liaw, B. Y.; Cooney, M. J. Curr. Opin. Biotechnol. 2007, 18, 228-234. (c) Kim, J.; Jia, H. F.; Wang, P. Biotechnol. Adv. 2006, 24, 296-308.

[6] (a) Willner, I.; Katz, E. Angew. Chem., Int. Ed. 2000, 39, 1180-1218. (b) Rusling, J. F.; Forster, R. J. J. Colloid Interface Sci. 2003, 262, 1-15. (c) Heller, A. J. Phys. Chem. 1992, 96, 3579-3587. (d) Ghindilis, A. L.; Atanasov, P.; Wilkins, E. Electroanalysis 1997, 9, 661-674. (e) Mano, N.; Mao, F.; Shin, W.; Chen, T.; Heller, A. Chem. Commun. 2003, 518-519. (f) Coman, V.; Vaz-Dominguez, C.; 
Ludwig, R.; Harreither, W.; Haltrich, D.; De Lacey, A. L.; Ruzgas, T.; Gorton, L.; Shleev, S. Phys. Chem. Chem. Phys., 2008, 10, 6093-6096.

[7] (a) Willner, I.; Heleg-Shabtai, V.; Blonder, R.; Katz, E.; Tao, G. J. Am. Chem. Soc. 1996, 118, 10321-10322. (b) Mao, F.; Mano, N.; Heller, A. J. Am. Chem. Soc. 2003, 125, 4951-4957.

[8] (a) Tayhas, G.; Palmore, R.; Kim, H. J. Electroanal. Chem. 1999, 464, 110-117. (b) Barton, S. C.; Gallaway, J.; Atanassov, P. Chem. Rev., 2004, 104, pp 4867-4886. (c) Scodeller, P.; Carballo, R.; Szamocki, R.; Levin, L.; Forchiassin, F.; Calvo, E. J. J. Am. Chem. Soc. 2010, 132, 11132-11140.

[9] Shleev, S.; Tkac, J.; Christenson, A.; Ruzgas T.; Yaropolov, A.; Whittaker, J.; Gorton, L. Biosens. Bioelectron., 2005, 20, 2517-2554.

[10] (a) Yaropolov, A. I.; Skorobogat'ko, O. V.; Vartanov, S. S.; Varfolomeyev, S. D. Appl. Biochem. Biotechnol. 1994, 49, 257-280. (b) Solomon, E. I.; Sundaram, U. M.; Machonkin, T. E.; Chem. Rev. 1996, 96, 2563-2605. (c) Morozova, O. V.; Shumakovich, G. P.; Gorbacheva, M. A.; Shleev, S. V.; Yaropolov, A. I.; Biochemistry (Moscow) 2007, 72, 1136-1150.

[11] Shleev, S.; Morozova, O.V.; Nikitina, V.O.; Gorshina, E.S.; Rusinova, T.V.; Serezhenkov, V.A.; Burbaev, D.S.; Gazaryan, I.G.; Yaropolov, A.I. Biochimie 2004, 86, 693-703.

[12] (a) Barton, S. C.; Kim, H.; Binyamin, G.; Zhang, Y.; Heller, A. J. Am. Chem. Soc. 2001, 123, 5802-5803.(b) Barriere, F.; Ferry, Y.; Rochefort, D.; Leech, D. Electrochem. Commun. 2004, 6, 237. (c) Ackermann, Y.; Guschin, D. A.; Eckhard, K.; Shleev, S.; Schuhmann, W. Electrochem. Commun. 2010, $12,640-643$.

[13] (a) Yaropolov, A. I.; Kharybin, A. N.; Emnéus, J.; Marko-Varga, G.; Gorton, L. Bioelectrochem. Bioenerg. 1996, 40, 49-57. (b) Shleev, S.; Jarosz-Wilkolazka, A.; Khalunina, A.; Morozova, O.; Yaropolov, A.; Ruzgas, T.; Gorton, L. Bioelectrochemistry 2005, 67, 115-124. 
[14] (a) Blanford, C. F.; Heath, R. S.; Armstrong, F. A. Chem. Commun. 2007, 1710-1712. (b) Vaz-

Dominguez, C.; Campuzano, S.; Rüdiger, O.; Pita, M.; Gorbacheva, M.; Shleev, S.; Fernandez, V. M.; De Lacey, A. L. Biosensors and Bioelectronics, 2008, 24 531-537.

[15] Ressine, A.; Vaz-Domínguez, C.; Fernandez, V. M.; De Lacey, A. L.; Laurell, T.; Ruzgas, T.; Shleev, S. Biosens. Bioelectron. 2010, 25, 1001-1007.

[16] O’Sullivan, C.; Crilly, S.; Laffir, F. R.; Singh, A.; Magner, E.; Ryan, K. M.Chem. Commun. 2011, 47, 2655-2657.

[17] Dagys, M.; Haberska, K. ; Shleev, S.; Arnebrant, T.; Kulys, J.; Ruzgas, T. Electrochem Commun. 2010, $12,933-935$.

[18] (a) Pita, M.; Shleev, S; Ruzgas, T.; Fernandez, V. M.; Yaropolov, A. I.; Gorton, L. Electrochem. Commun. 2006, 8, 747-753. (b) Gupta, G.; Rajendran, V.; Atanassov, P. Electroanalysis 2004, 16, $1182-1185$.

[19] Gonzalez-Arzola, K.; Gimeno,Y.; Arevalo, M.C.; Falcon, M.A.; Hernandez-Creus, A. Bioelectrochemistry 2010, 79, 17-24.

[20] (a) Delamar, M.; Hitmi, R.; Pinson, J.; Saveant, J. M. J. Am. Chem. Soc. 1992, 114, 5883-5884. (b) Allongue, P.; Delamar, M.; Desbat, B.; Fagebaume, O.; Hitmi, R.; Pinson, J.; Saveant, J. M. J. Am. Chem. Soc. 1997, 119, 201-207.

[21] (a) Bernard, M.; Chausse, A.; Cabet-Deliry, E.; Chehimi, M. M.; Pinson, J.; Podvorica, F.; Vautrin-Ul, C. Chem. Mater. 2003, 15, 3450-3462. (b) Liu, G.; Liu, J.; Böcking, T.; Eggers, P. K.; Gooding, J. J. Chem. Phys. 2005, 319, 136-146. (c) Lyskawa, J.; Belanger, D. Chem. Mater. 2006, 18, $4755-4763$

[22] Laforge, A.; Addou, T.; Belanger, D. Langmuir 2005, 21, 6855-6865. 
[23] Polsky, R.; Harper, J. C.; Dirk, S. M.; Arango, D. C.; Wheeler, D. R.; Brozik, S. Langmuir 2007, $23,364-366$.

[24] Radi, A.; Muñoz-Berbel, X.; Cortina-Puig, C.; Marty, J. Electroanalysis, 2009, 21 (6), 696 - 700.

[25] Bradford, M.M. Anal. Biochem. 1976, 72, 248-254.

[26] Oesch, U.; Janata, J. Electrochim. Acta 1983, 28, 1237-1246.

[27] Benedetto, A.; Balog, M.; Viel, P.; Le Derf, F.; Salle, M.; Palacin, S. Electrochimica Acta 2008, $53,7117-7122$.

[28] Brooksby, P. A.; Downard, A. J. Langmuir 2004, 20, 5038-5045.

[29] Liu, Y. C.; McCreery, R. L. J. Am. Chem. Soc. 1995, 117, 11254-11259.

[30] Widrig, C. A.; Chung, C.; Porter, M. D. J. Electroanal. Chem. 1991, 310, 335-359.

[31] Shewchuk, D. M.; McDermott, M. T. Langmuir 2009, 25(8), 4556-4563.

[32] Kummer, K.; Vyalikh, D. V.; Gavrila, G.; Kade, A.; Weigel-Jech, M.; Mertig, M.; Molodtsov, S. L. J. Electron. Spectrosc. 2008, 163, 59-64.

[33] Piontek, K.; Antorini, M.; Choinowski, T. J. Biol. Chem., 2002, 277, 37663-37669.

[34] Lyskawa, J.; Belanger, D. Chem. Mater. 2006, 18, 4755-4763.

[35] Liu, G.; Böcking, T.; Gooding, J. J. J. Electroanal. Chem. 2007, 335-344.

[36] Pershad, H. R.; Duff, J. L. C.; Heering, H. A. ; Duin, E. C.; Albracht, S. P. J.; Armstrong, F.A. Biochemistry 1999, 38, 8992-8999.

[37] Sosna, M.; Chretien, J. M.; Kilburn, J. D.; Bartlett, P. N. Phys. Chem. Chem. Phys. 2010, 12, 10018-10026. 
[38] Johnson, D. L.; Thompson, J. L.; Brinkmann, S. M.; Schuller, K. A.; Martin, L. L. Biochemistry 2003, 42, 10229-10237.

[39] Qiu, H.; Xu, C.; Huang, X.; Ding, Y.; Qu, Y.; Gao, P. J. Phys. Chem. C 2008, 112, 14781-14785.

[40] Thorum, M. S.; Anderson, C. A.; Hatch, J. J.; Campbell, A. S.; Marshall, N. M., Zimmerman, S. C.; Lu, Y.; Gewirth, A. A. J. Phys. Chem. Lett. 2010, 1, 2251-2254.

[41] Sucheta, A.; Cammack, R.; Weiner, J.; Armstrong, F.A. Biochemistry 1993, 32, 5455-5465.

[42] Leger, C.; Jones, A. K.; Albracht, S. P. J.; Armstrong, F. A. J. Phys. Chem B 2002, 106, 1305813063.

[43] Polyakov, K. M.; Fedorova, T. V.; Stepanova, E. V.; Cherkashin, E. A.; Kurzeev, S. A.; Strokopytov, B. V.; Lamzin, V. S.; Koroleva, O. VActa Cryst. 2009, D65, 611-617.

[44] Stoica, L.; Dimcheva, N.; Haltrich, D.; Ruzgas, T.; Gorton, L. Biosens. Bioelectron. 2005, 20, 2010-2018. 


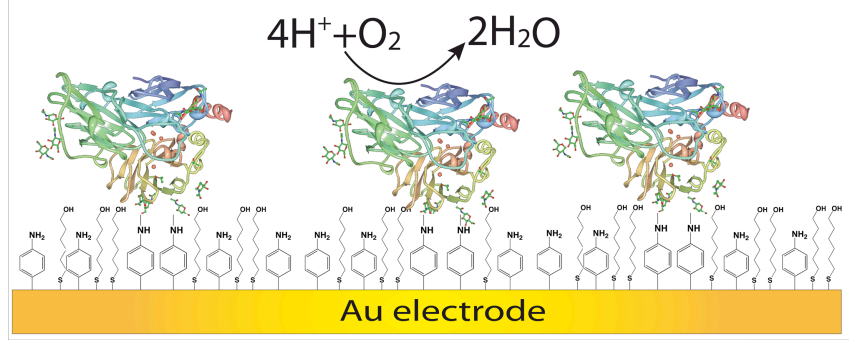

SYNOPSIS TOC 


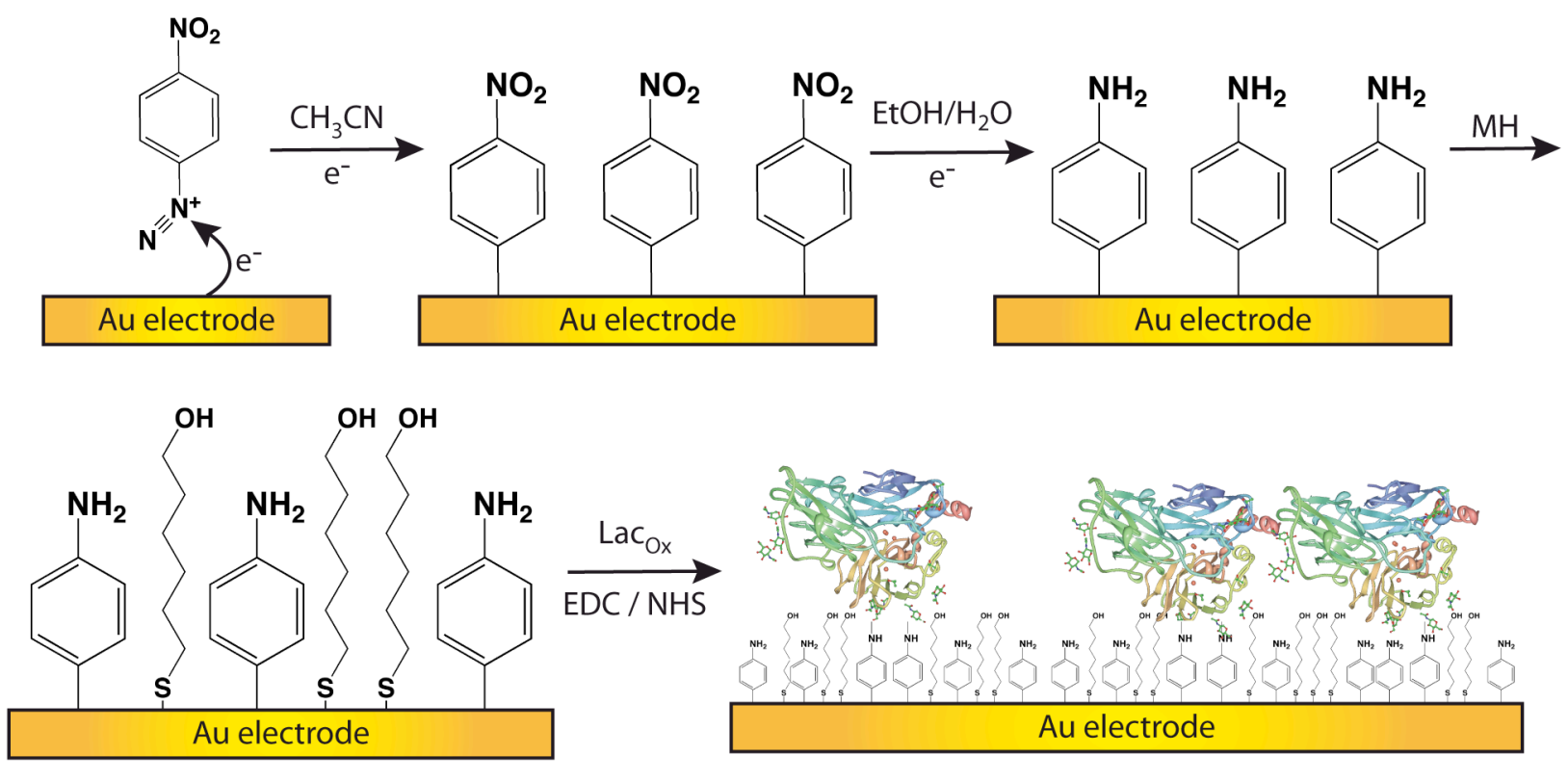

SCHEME 1 

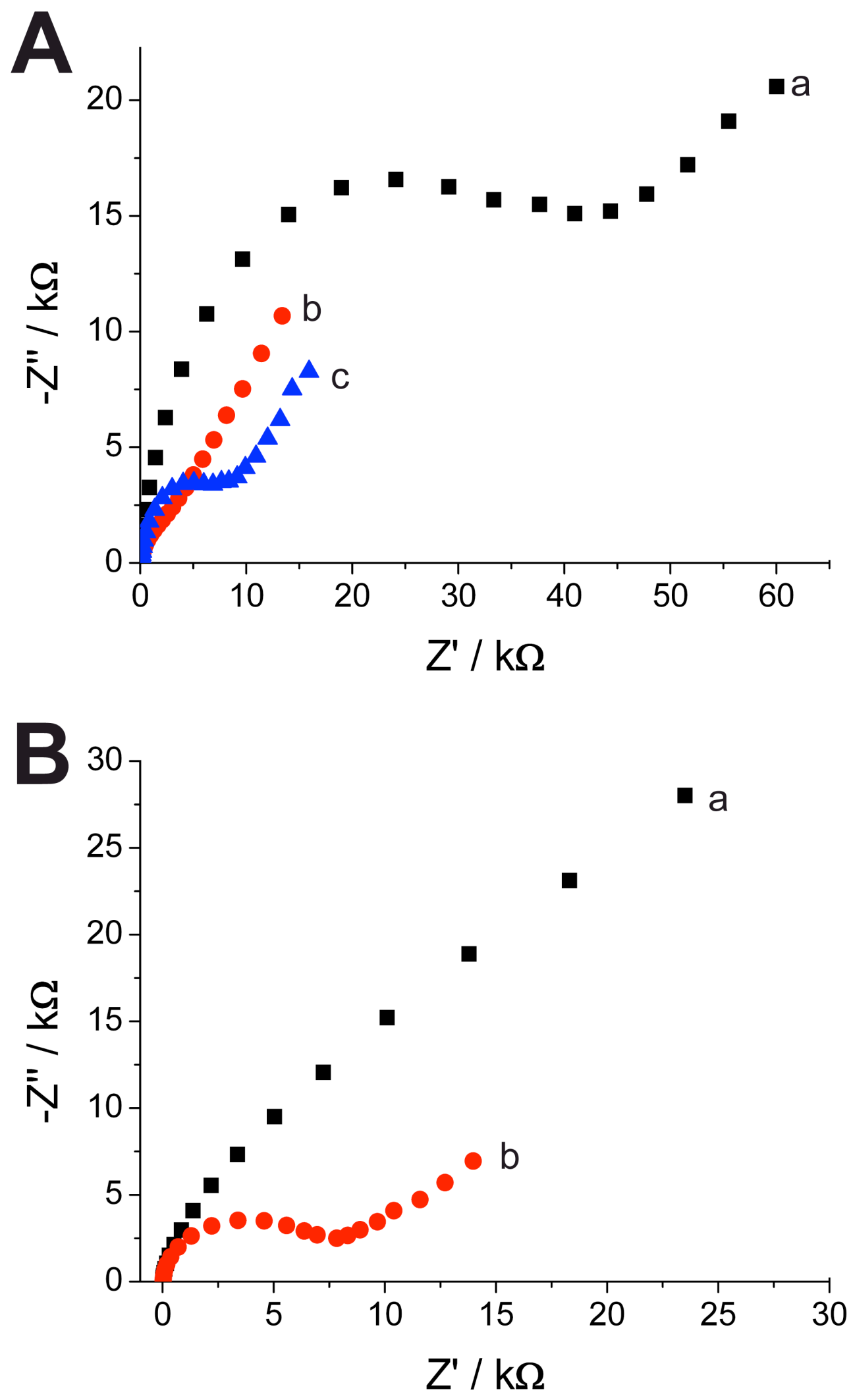

Figure 1. Impedance Spectra. 

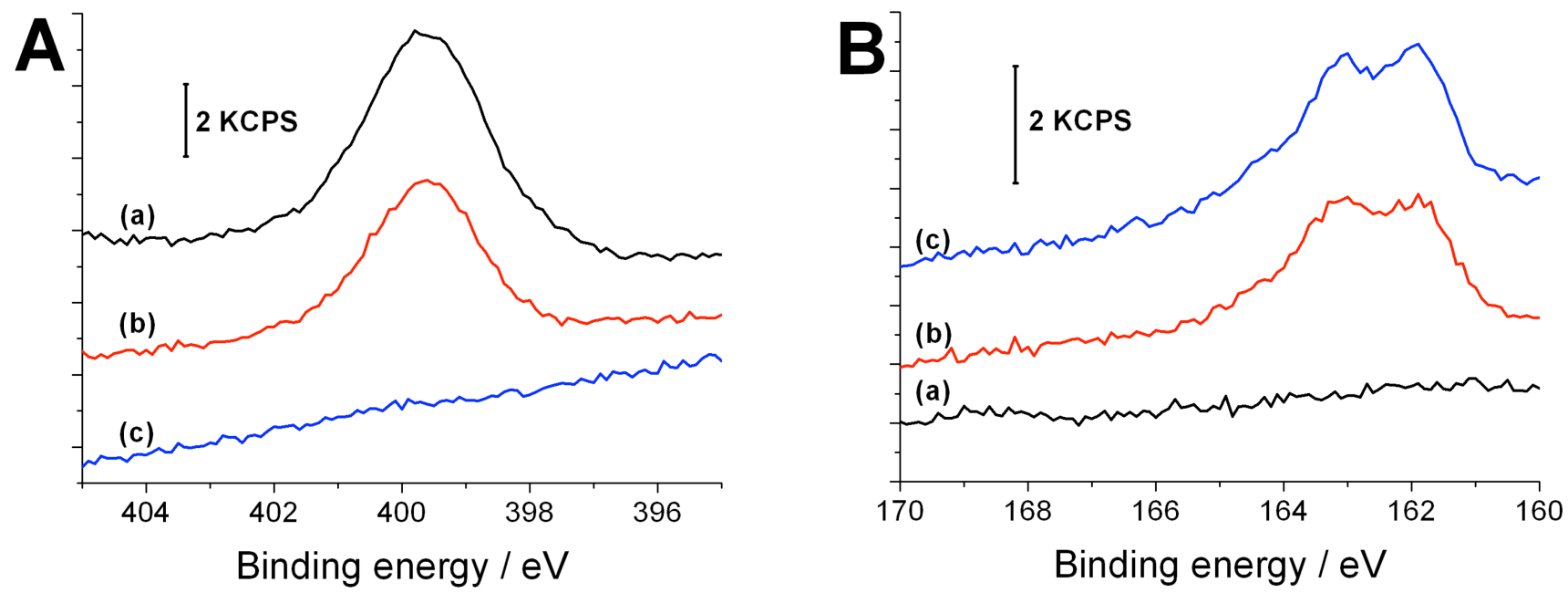

Figure 2. XPS core N 1s and S 2p spectra. 


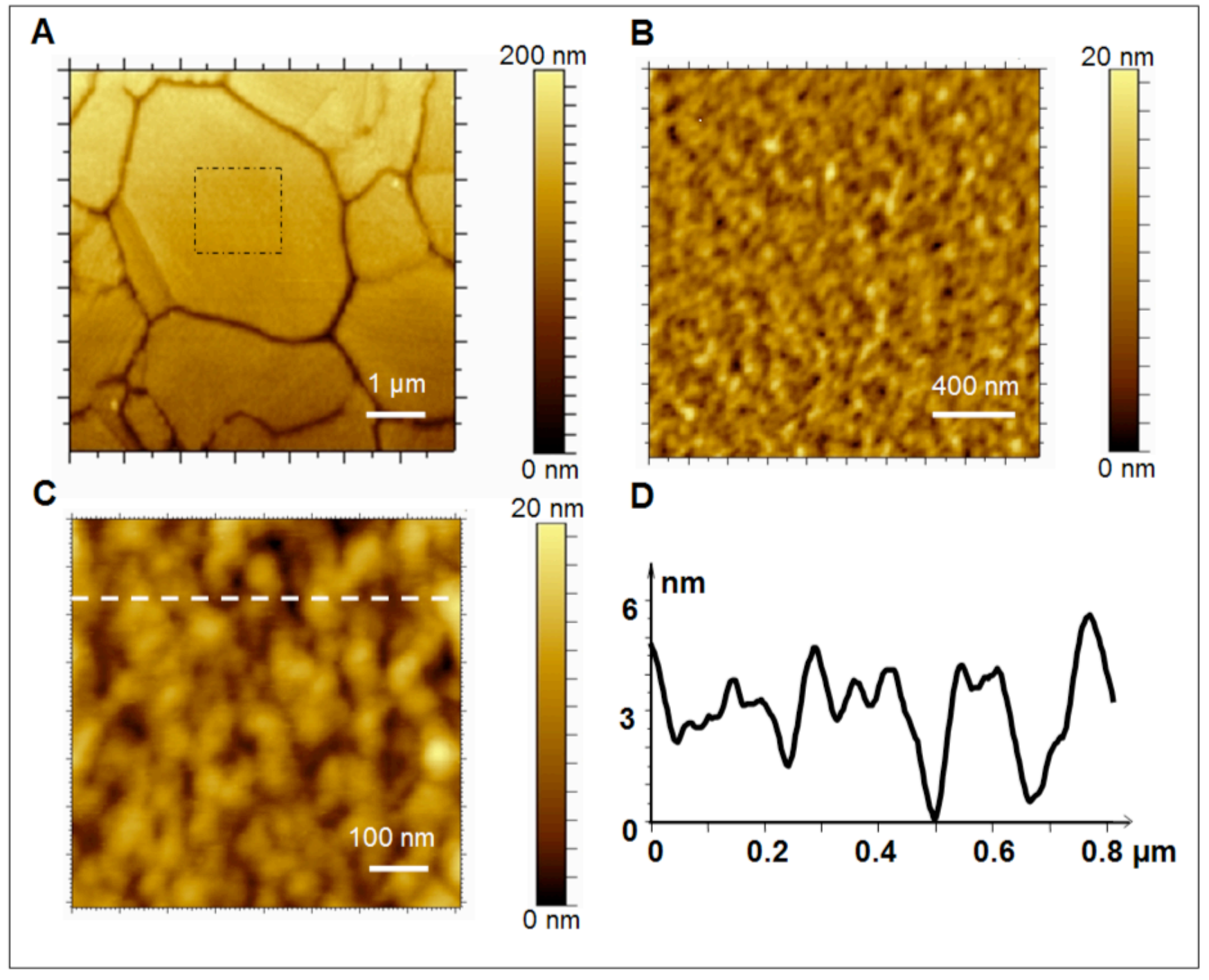

Figure 3. AFM images of a laccase-modified Au surface. 

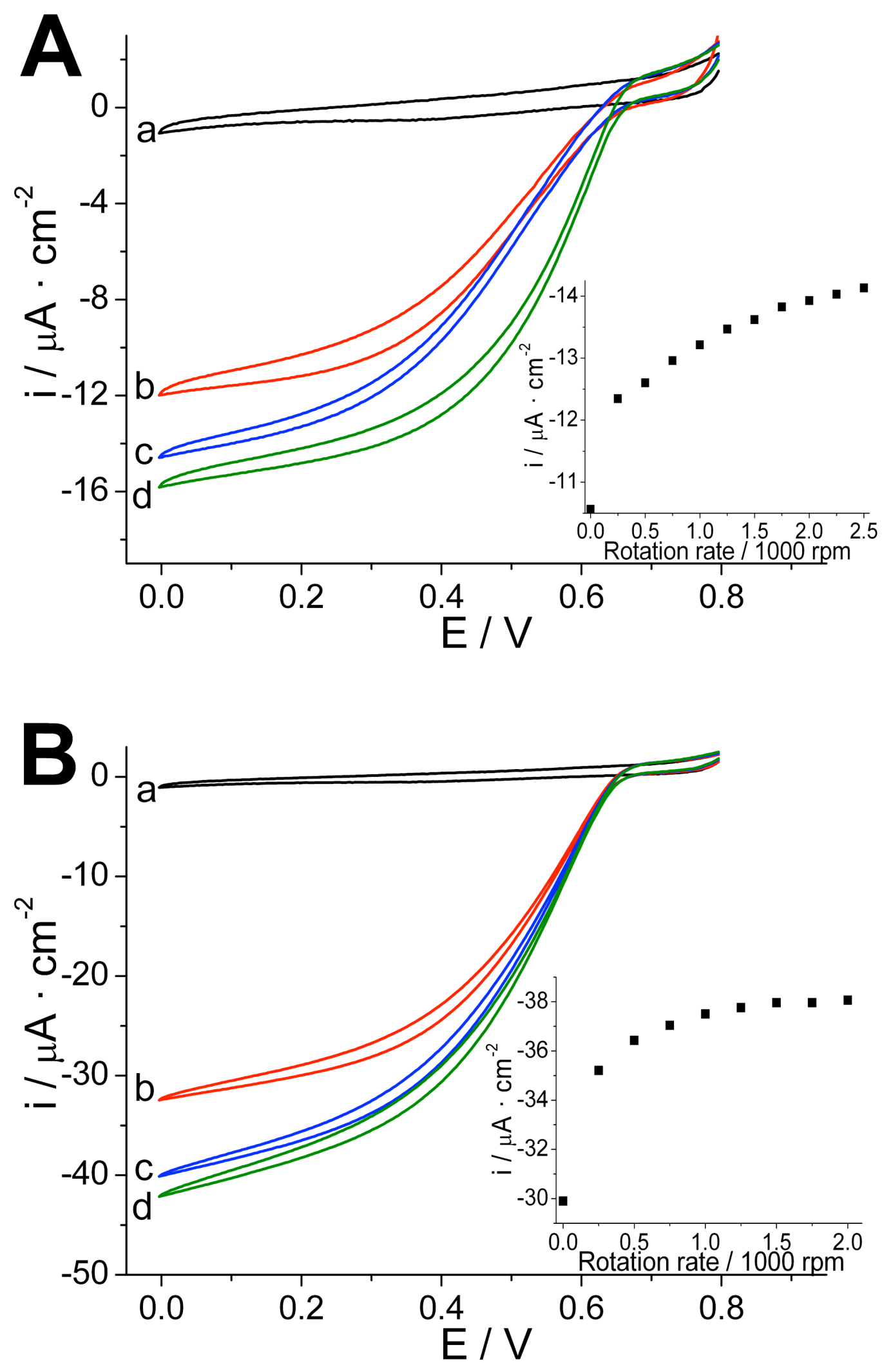

Figure 4. Bioelectrocatalytic reduction of Oxygen. 

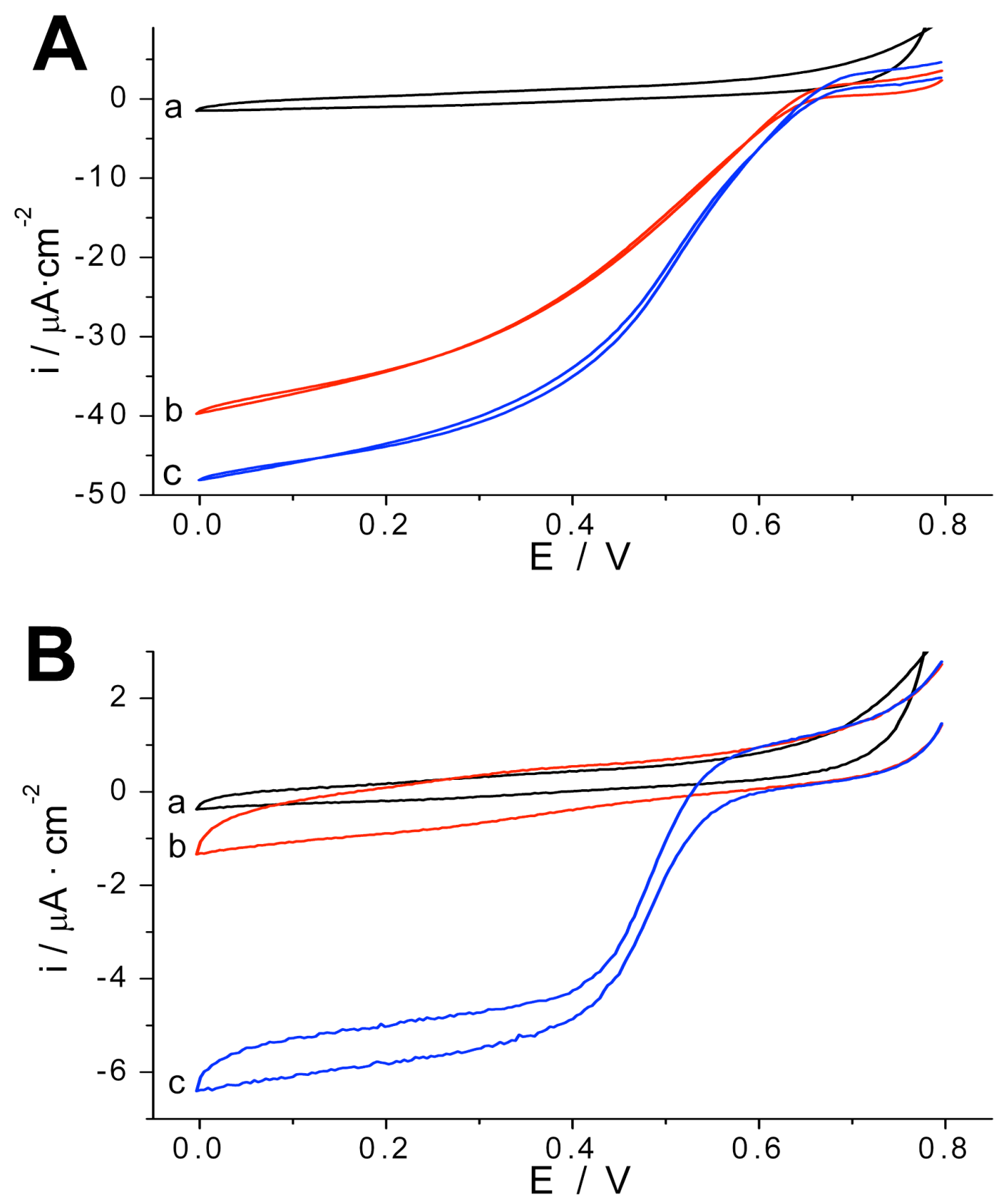

Figure 5. DET-MET and Schiff-EDC vs. EDC only. 


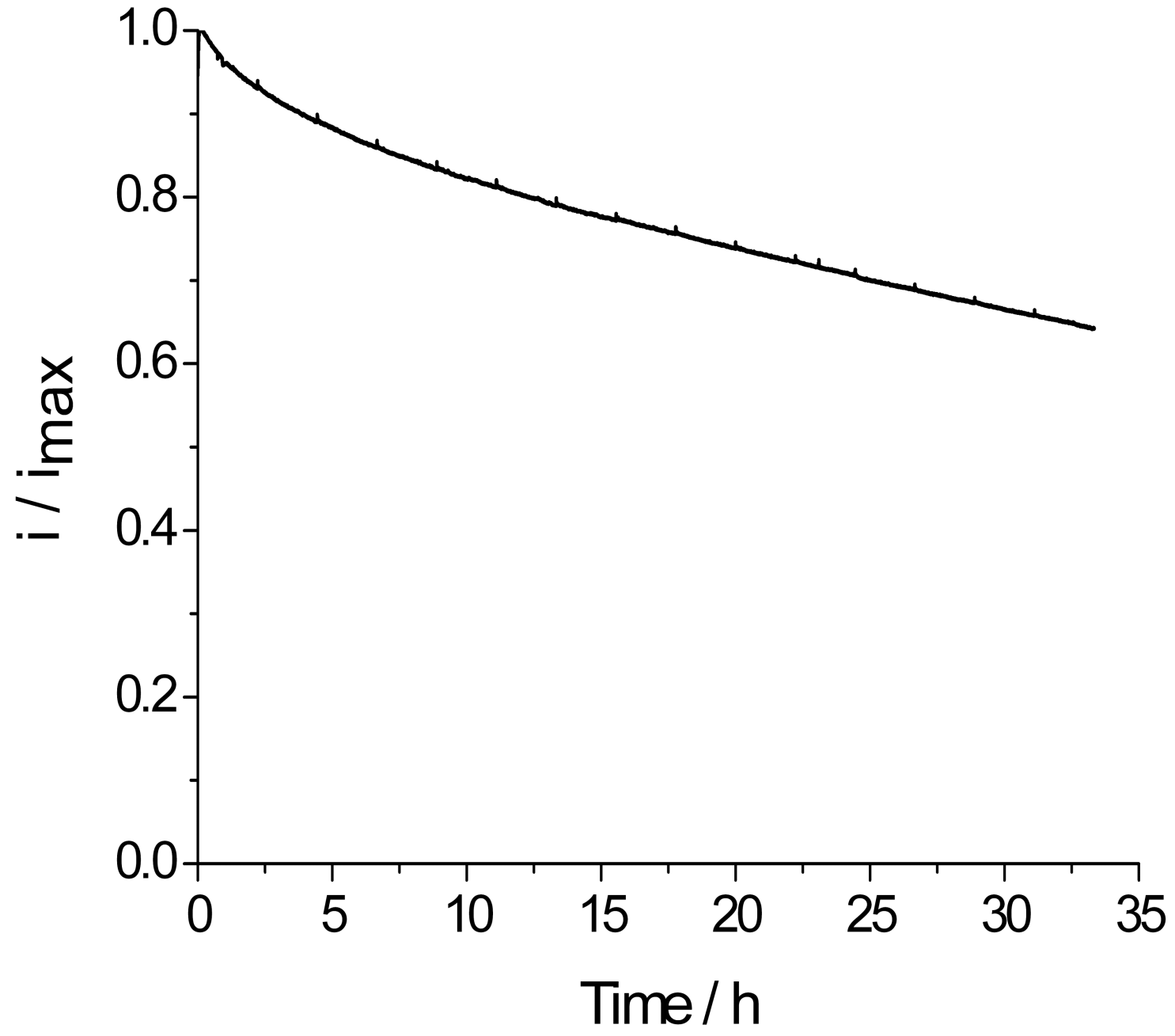

Figure 6. Stability of the bioelectrocatalytic current of oxygen reduction by a laccase-modified electrode over 33 hours. 